\title{
Research and Imagination in the Twenty-First Century: Liberal Arts and Sciences
}

\author{
Danny Anderson
}

Dean, College of Liberal Arts and Sciences, University of Kansas

$\mathrm{T}$

o think outside the box. To take off the blinders. To "blue sky" about an issue. To connect the dots in a new way. To look at things differently. To see from a new perspective. To use a new lens. These phrases are just a few of the everyday reminders that encourage insightful creativity. It is this range of habits of mind that I evoke with the word "imagination." Within the context of an international public research university like the University of Kansas, I see the work of the liberal arts and sciences as drivers of the imagination within our research mission. The liberal arts and sciences are foundational for sustaining and enhancing the research mission of public universities in the twenty-first century. And it is the imagination fostered by a liberal arts and sciences education that lays this foundation.

The twenty-first century has begun with a conversation about higher education, mainly focusing on challenges and obstacles. Political and social satirist Grant Snider, in his sketch "The University of Awesome," caricatures a large research university as a map of campus landmarks, ranging from the "Pit of Parental Expectations" in the foreground through buildings renamed to question their relevance and immediate utility for employment, all the way to the shining city of "Reality" located at the far horizon. The elements parodied in Snider's drawing are stated more seriously in discussions about tuition, accessibility, and accountability, which are key words used today by policy-makers and consumers. On public television, a documentary like Declining By Degrees portrays many of the challenges and short-comings of the present system. Educational scholar and leader Derek Bok, with his book Our Underachieving Colleges: A Candid Look at How Much Students Learn and Why They Should Be Learning More, diagnoses the obstacles for achieving the ideals of a liberal arts and sciences education. In his inaugural address, President Barack Obama voiced the commitment to "transform our schools and colleges and universities to meet the demands of a new age."

Both the American Association of Universities (AAU) and the Association of Public and Land-Grant Universities (APLU) have weighed in on this conversation as it has related to research universities. Robert Berdahl, President of the AAU at one point speculated on whether the United States would need 
"fewer but better" research universities. Peter McPherson, Howard Gobstein, and David Shulenburger, of the APLU, have extensively analyzed the future of public research universities, examining their funding mechanisms and contributions to United State economic development and competitiveness as well as strategies for ensuring their future contributions.

While this conversation is robust, one topic is missing: the role of liberal arts and sciences within public research universities. At the Council of College of Arts and Sciences, there is excellent preparation for this conversation with a brochure of frequently asked questions contributed by Matthew C. Moen. And the American Association of Colleges and Universities has foregrounded the liberal arts in a campaign about American's promise that will continue through 2015. The Chronicle of Higher Education in a special group of articles (5 March 2010) discussed "the new liberal arts" in private liberal arts college, regional state universities, online/for-profit institutions, and honors programs in large state universities. In each of these cases, workforce development and rising enrollment in professional programs are the drivers behind the new liberal arts.

But these FAQs, campaigns, and proposals for the new liberal arts have not yet examined the foundational role of liberal arts and sciences in the public research university. In a large public research university, the college of liberal arts and sciences is usually the administrative cornerstone for the institution. It serves as a home for many of the general education goals. It provides the breadth and depth of majors sought by students. It provides the key opportunities for directly engaging undergraduates in research with faculty. And its doctoral programs and the research relationship forged between graduate students and faculty are frequently taken as measures of the institution's stature as a research university. With the foundational importance that the liberal arts and sciences play in this role, it is crucial to understand how they foster the imagination needed to ensure prosperity in the future.

Within a public research university, the liberal arts and sciences are not only foundational in sustaining and enhancing research in these many different forms. They are also the intellectual home for students who seek an education that allows them to learn to think like researchers who can imagine and innovate, that shows them how to test ideas while learning about failure and success when taking intellectual risks, that pushes them to develop original solutions to complex problems, and that propels them to rely upon their imagination when visioning the world of the future. Whereas the OED pushes us to conceptualize "research" as goal oriented, "pursuing a specified thing or person," the imagination broadens research. The liberal arts and sciences are home to applications and translations, but they are also the dwelling place of basic research that 
creates the conditions for future applications and translations.

Journalist Thomas Friedman, in his often cited book The World is Flat: A Brief History of the Twenty-First Century, notes that:

Liberal arts is a very horizontal form of education (which is to say, a flat form of education). It is all about making connections among history, art, politics, and science. Yes, we need to be more rigorous in training our young people in math and science, which are the building blocks of so much knowledge. But we also need to be vigilant in upholding the teaching of art and music and literature, because they too are essential for innovation. (316)

Friedman's linkage between liberal arts and sciences (with the juxtaposition of different disciplines and perspectives) and innovation is the combination that I am seeking to evoke with the word imagination. Imagination is creative power, the ability to create what does not yet exist in response to the situations, opportunities, challenges, and problems that confront us. This reality should inform the role of a dean of liberal arts and sciences within a public research university.

As James Moeser reminds us, a university leader is also a cheerleader-inchief. In this case, the dean of liberal arts and sciences at a public research university is cheerleader-in-chief for the imagination and for the ways that liberal arts and sciences enhance and sustain research. There are multiple ways that this responsibility must be fulfilled vis-àvis the varied nature of liberal arts and sciences. Here are a few examples that range across the liberal arts and sciences.

- In a world driven by the bottom-line and immediate application, the dean must not only promote strong translational research in the natural sciences but also defend pure imagination represented by "basic research," defined by the National Science Foundation as "pursuit of new scientific knowledge or understanding that does not have specific immediate commercial objectives...."Research imagination may begin with the known, but it also explores the possible that may not yet be reducible to "immediate commercial objectives."

- In a world made smaller by technology, the differences among cultures and languages can loom even larger. Cultural research, area studies work, and combinations of language and literary studies all advance the global imagination that creates bridges across these differences. As Catherine Porter, former president of the Modern Language Association, has noted, it is through these experiences that students "learn to empathize with people unlike themselves and to imagine themselves in situations unlike their own." Research toward cultural aptitude enhances the global imagination.

In a world made smaller by technology, humanities research also has a special role to play in sustaining democracy. As philosopher Martha Nussbaum underscores, "the ability to imagine the experience of another $[. .$.$] needs to be$ greatly enhanced and refined if we are to have any hope of sustaining decent institutions across the many divisions that any modern society contains" (10). Alongside the scientific and global aspects of the imagination, humanities encourage the moral imagination that sustains civility and helps us understand our complex world.

In a world made up of multiple and varied forms of expression, research into the arts is fundamental. The arts 
give voice, form, and shape to individual yearnings as well as collective aspirations and shared understandings. Creative production and research into the arts informs our understanding of imagination as creative impulse as well as active audience engagement with the construction of meaning through the aesthetic imagination.

- Finally, in a world shaped by data, information, media, and representations, research in the social and behavioral sciences plays a fundamental role in understanding the conditions of our existence. Sociologist Arjun Appadurai analyzes the dynamics of life at the end of the twentieth century and notes: "The image, the imagined, the imaginarythese are all terms that direct us to something critical and new in global cultural processes: the imagination as a social practice. [...] [T] he imagination has become an organized field of social practices..." (31).

Taking these ideas one step further, the role of the imagination-fostered through the liberal arts and sciences-is foundational for the goals of professional education, especially as recently articulated by the National Academies in the report Rising Above the Gathering Storm: Energizing and Employing America for a Brighter Economic Future. The global challenges in crosscultural relations and understanding, demographic flows, security, energy, environment, communications, trade, and economic interconnections must be addressed by the imagination on the way to creating new realities. As Thomas Friedman notes in his concluding chapter to The World is Flat, imagination is a critical enabler for the United States:

[Imagination] has never been more important than now, because in a flat world so many of the tools of collaboration are becoming commodities available to everyone. So many more individuals have the power to create their own content and globalize it. There is one thing, though that has not and can never be commoditized, and that is imagination-what content we dream of creating. (608-09)

It is the goal of the liberal arts and sciences to propel and energize the imagination, to remove the limits to the content we can dream of creating.

These dreams are crucial for our globe, but they are also crucial for our homes, for the quality of our everyday lives. Writer and thinker Wendell Berry often reminds us to bring the lofty back to the practical, back to our roots. In closing, I want to recast Berry's words about the mission of education to describe the mission of the imagination when engaged in research. Research and imagination, while directed toward the possible future, are also rooted in the present, in our communities. The liberal arts and sciences are foundational at a research university because the research they promote "in the true sense [...] is an enablement to serve... And if this research is to be used well, it is obvious that it must be used some where; it must be used where one lives, where one intends to continue to live; it must be brought home" (52, with my modifications). The liberal arts and sciences are an intellectual home for the imagination, and through the 
imaginative acts we encourage, we bring our research home to improve our lives.

\section{Works Cited}

Appadurai, Arjun. Modernity at Large: Cultural Dimensions of Globalization. Minneapolis: $\mathrm{U}$ of Minnesota P, 1996.

Berry, Wendell. "Higher Education and Home Defense." Home Economics. San Francisco: North Point P, 1987. 49-53.

Bok, Derek. Our Underachieving Colleges: A Candid Look at How Much Students Learn and Why They Should be Learning More. Princeton: Princeton UP, 2006.

Friedman, Thomas. The World Is Flat: A Brief History of the Twenty-First Century, 3.0. New York: Picador/Farrar, Straus and Giroux, 2007. McPherson, Peter, Howard Gobstein, and David Shulenburger. "Ensuring Public Research Universities Remain Vital." Discussion Draft. Association of Public and Land-Grant Universities. July 1, 2010.
Moen, Matthew C. "Liberal Arts and Sciences FAQ." Williamsburg, Virginia: Council of Colleges of Arts and Sciences, n.d.

National Academy of Science, National Academy of Engineering, and Institute of Medicine. Rising Above the Gathering Storm: Energizing and Employing America for a Brighter Economic Future. Washington, D.C.: The National Academies Press, 2007.

Nussbaum, Martha C. Not for Profit: Why Democracy Needs the Humanities. Princeton: Princeton UP, 2010.

Porter, Catherine. MLA Newsletter Spring 2009. Snider, Gary. "The University of Awesome!" The Kansas City Star 10 June 2010: 31.

"The New Liberal Arts." Chronicle of Higher Education 5 March 2010. 